\title{
p-tert-Butyl Thiacalix[4]arene Derivatives Functionalized in the Lower Rim with Bis(3-aminopropyl)amine: Synthesis and Interaction with DNA
}

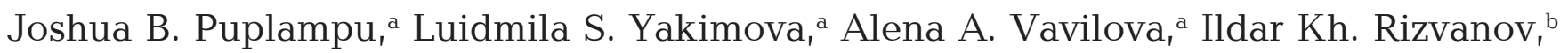 \\ and Ivan I. Stoikova@ \\ ${ }^{a}$ Kazan Federal University, A.M. Butlerov Chemical Institute, 420008 Kazan, Russian Federation \\ 'A.E. Arbuzov' Institute of Organic and Physical Chemistry of KSC RAS, 420088 Kazan, Russian Federation \\ ${ }^{\circledR}$ Corresponding authorE-mail: ivan.stoikov@mail.ru
}

\begin{abstract}
New tetrasubstituted derivatives of thiacalix[4]arene functionalized with bis(3-aminopropyl)amide fragments at the lower rim in the cone and 1,3-alternate conformations have been synthesized. It was demonstrated that the synthesized thiacalix[4]arenes derivatives interact with DNA resulting in a shift in absorption maxima to $257 \mathrm{~nm}$ with clear isosbestic point at $300 \mathrm{~nm}$.
\end{abstract}

Keywords: Thiacalix[4]arene, synthesis, molecular recognition, macrocycles, DNA.

\section{Производные $n$-трет-бутилтиакаликс[4]арена, функционализированные по нижнему ободу бис(3-аминопропил)амином: синтез и взаимодействие с АНК}

\author{
А. Б. Пуплампу, ${ }^{\text {a }}$ А. С. Якимова, ${ }^{\text {a }}$ А. А. Вавилова, ${ }^{a}$ И. Х. Ризванов, ${ }^{b}$ \\ И. И. Стойков ${ }^{\mathrm{a}}$

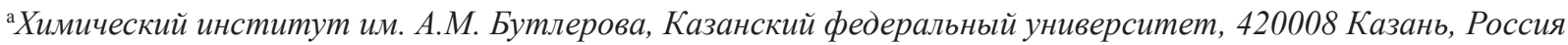 \\ ${ }^{\mathrm{b}}$ Институт органической и физической химии им. А. Е. Арбузова Казанского научного иентра РАН, 420088 Казань, \\ Россия
}

\begin{abstract}
Новые производные тиакаликс[4]арена, функционализированные по нижнему ободу бис(3-аминопропил) амидньми фрагментами, в конфигурациях конус и 1,3-альтернат проявили взаимодействие с ДНК.
\end{abstract}

Ключевые слова: Тиакаликс[4]арены, синтез, молекулярное распознавание, макроциклы, ДНК.

\section{Introduction}

Molecules which can bind nucleic acids have prospective applications in the development of therapeutics, diagnostics, bionanomaterials and gene delivery systems. Among such potential molecules, those which can further compact DNA molecules into nanosized particles following molecular recognition can aid transport of DNA into the cells. ${ }^{[1,2]}$ Molecular recognition of the nucleotides by natural polyamines, ${ }^{[3,4]}$ synthetic macrocyclic polyamine receptors, ${ }^{[5-9]}$ polyamine polymers ${ }^{[10,11]}$ and dendrimers ${ }^{[12,13]}$ has been demonstrated. It was shown that the efficiency of the cell transfection and cytotoxicity positively correlate with the ratio of amino groups in receptor molecule to the number of phosphate groups in the DNA molecule (N/P).$^{[14-17]}$ Also, the molecular weight, ${ }^{[18]}$ degree of branching and structural flexibility, ${ }^{[19]}$ and cationic charge density ${ }^{[20]}$ correlate with both transfection efficiency and toxicity. Thus, in order to develop the vector with high transfection efficiency and low toxicity, all these factors should be considered. 
Recent functionalization of relatively small calixarene macrocycle with cationic groups ${ }^{[17,21]}$ resulted in good complexation and transfection capabilities with relatively low toxicity. Our research group recently showed that the guanidine functionalized thiacalix[4]arenes interacted with DNA. ${ }^{[5]}$ We believe that the thiacalix[4]arene platform with relatively large cavity size and variable conformations ${ }^{[22]}$ with different spatial orientation of the functional groups, when functionalized with analogs of natural oligoamines may result in efficient vectors with low toxicity.

In this study, we describe the synthesis of the $p$-tert-butylthiacalix[4]arenes functionalized with bis(3aminopropyl)amine fragments at the lower rim in cone and 1,3-alternate conformations and their interaction with calf thymus DNA (CT-DNA).

\section{Experimental}

\section{General}

The ${ }^{1} \mathrm{H}$ and ${ }^{13} \mathrm{C}$ NMR spectra were recorded on the Bruker Avance-400 (400 MHz) spectrometer. Chemical shifts were determined relative to the signals of residual protons of the deuterated solvent $\left(\mathrm{CDCl}_{3}\right)$. The concentration of the sample solution was $3-5 \%$

Most chemicals were purchased from Aldrich and used as received without additional purification. Organic solvents were purified by standard procedures.

Attenuated total internal reflectance IR spectra were recorded with Spectrum 400 (Perkin Elmer) Fourier spectrometer.

Elemental analysis was performed with Perkin Elmer 2400 Series II instrument.

The mass spectra were obtained on Bruker Ultraflex III MALDI-TOF instrument using 2,5-dihydroxybenzoic acid and $p$ nitroaniline matrices.

Melting points were determined using the Boetius Block apparatus.

Additional control of purity of the compounds and monitoring of the reaction was carried out by thin-layer chromatography using Silica G, $200 \mu \mathrm{m}$ plates, UV 254

Tetraesters 1 and $\mathbf{2}$ of $p$-tert-butylthiacalix[4]arene in cone and 1,3-alternate conformations, respectively, ${ }^{[23]}$ and bis(3-aminopropyl)amine were used as initial reagents.

\section{Synthesis of Compound 3}

To $p$-tert-butylthiacalix[4]arene $1(0.50 \mathrm{~g}, 0.47 \mathrm{mmol})$ was added bis(3-aminopropyl)amine $1.5 \mathrm{ml}(10.72 \mathrm{mmol})$. The reaction mixture was stirred under argon for $72 \mathrm{hrs}$ at $60^{\circ} \mathrm{C}$. The ethanol by-product was removed under reduced pressure. The unreacted bis(3-aminopropyl)amine was removed by diethyl ether $(3 \times 30 \mathrm{ml})$ and a thick viscous product was obtained. The product was then dried under reduced pressure over sodium hydroxide.

5,11,17,23-Tetra-tert-butyl-25,26,27,28-tetra-[N-(1'-(4',8'diazaoctyl)-carbamoylmethoxy)]-2,8,14,20-tetrathiacalix [4] arene (cone-3). White powder, yield: $0.34 \mathrm{~g}(51 \%)$. Mp: $107^{\circ} \mathrm{C}$. ${ }^{1} \mathrm{H}$ NMR $\left(\mathrm{CDCl}_{3}\right) \delta_{\mathrm{H}} \mathrm{ppm}(\mathrm{J} / \mathrm{Hz}): 1.11\left(\mathrm{~s}, 36 \mathrm{H},\left(\mathrm{CH}_{3}\right)_{3} \mathrm{C}\right), 1.76$ (m, 16H, $-\mathrm{NHCH}_{2} \mathrm{CH}_{2} \mathrm{CH}_{2}$ ), $2.64\left(\mathrm{~m}, 8 \mathrm{H},-\mathrm{NHCH}_{2} \mathrm{CH}_{2} \mathrm{CH}_{2} \mathrm{NH}_{2}\right.$ ), $2.73\left(\mathrm{~m}, 8 \mathrm{H},-\mathrm{CH}_{2} \mathrm{CH}_{2} \mathrm{NHCH}_{2} \mathrm{CH}_{2} \mathrm{CH}_{2} \mathrm{NH}_{2}\right), 2.85$ (br. s, 8H, $\left.-\mathrm{CH}_{2} \mathrm{CH}_{2} \mathrm{CH}_{2} \mathrm{NH} \mathrm{H}_{2}\right), 3.42\left(\mathrm{~m}, 16 \mathrm{H},-\mathrm{NHCH}_{2} \mathrm{CH}_{2} \mathrm{CH}_{2}\right), 4.81(\mathrm{~s}, 8 \mathrm{H}$, $-\mathrm{OCH}_{2} \mathrm{C}(\mathrm{O}) \mathrm{NH}$ ), 4.93 (br. m, 4H, $-\mathrm{CH}_{2} \mathrm{NHCH}_{2} \mathrm{CH}_{2}$ ), 7.33 (s, 8H, ArH), 8.27 (br.t, $\left.4 \mathrm{H},{ }^{3} \mathrm{~J}_{\mathrm{HH}}=5.8 \mathrm{~Hz},-\mathrm{C}(\mathrm{O}) \mathrm{NH}\right) .{ }^{13} \mathrm{C} \mathrm{NMR}\left(\mathrm{CDCl}_{3}\right)$ $\delta_{\mathrm{C}}$ ppm: $168.37,157.69,147.45,134.83,128.13,74.47,47.98,47.79$, 40.49, 37.49, 34.26, 33.74, 31.10, 29.69. IR $v \mathrm{~cm}^{-1}: 3297(\mathrm{NH}) ; 1661$,
$1541(\mathrm{C}(\mathrm{O}) \mathrm{NH})$. MALDI-TOF MS: calculated $\left[\mathrm{M}^{+}\right] \mathrm{m} / \mathrm{z}=1404.8$, found $[\mathrm{M}+\mathrm{H}]^{+} m / z=1405.9$. Found: $\mathrm{C}, 61.10 ; \mathrm{H}, 8.44 ; \mathrm{N}, 12.08 ; \mathrm{S}$, 8.26. Calculated for $\mathrm{C}_{72} \mathrm{H}_{120} \mathrm{~N}_{16} \mathrm{O}_{8} \mathrm{~S}_{4}: \mathrm{C}, 61.50 ; \mathrm{H}, 8.32 ; \mathrm{N}, 11.95 ; \mathrm{S}$, $9.12 \%$.

\section{Synthesis of Compound 4}

To a solution of p-tert-butylthiacalix[4]arene $2(0.50 \mathrm{~g}$, $0.47 \mathrm{mmol})$ in a mixture of toluene and methanol $(30 \mathrm{ml}, 3: 1, \mathrm{v}: \mathrm{v})$ was added bis(3-aminopropyl)amine $(1.5 \mathrm{ml}, 10.72 \mathrm{mmol})$. The reaction mixture was refluxed under argon for $72 \mathrm{hrs}$. The ethanol by-product was removed under reduced pressure and unreacted bis(3-aminopropyl)amine with diethyl ether $(3 \times 30 \mathrm{ml})$. The viscous product left was then dried under reduced pressure over sodium hydroxide.

5,11,17,23-Tetra-tert-butyl-25,26,27,28-tetra-[N-(1'-(4',8'diazaoctyl)-carbamoylmethoxy)]-2,8,14,20-tetrathiacalix[4]arene (1,3-alternate-4). Paleyellow powder, yield: $0.44 \mathrm{~g}(66 \%)$. Mp: $97^{\circ} \mathrm{C}$. ${ }^{1} \mathrm{HNMR}\left(\mathrm{CDCl}_{3}\right) \delta_{\mathrm{H}} \mathrm{ppm}(\mathrm{J} / \mathrm{Hz}): 1.22\left(\mathrm{~s}, 36 \mathrm{H},\left(\mathrm{CH}_{3}\right)_{3} \mathrm{C}-\right), 1.67(\mathrm{p}, 8 \mathrm{H}$, $\left.-\mathrm{NHCH}_{2} \mathrm{CH}_{2} \mathrm{CH}_{2} \mathrm{NH}_{2}\right), 1.79$ (p, $\left.8 \mathrm{H},-\mathrm{C}(\mathrm{O}) \mathrm{NHCH}_{2} \mathrm{CH}_{2} \mathrm{CH}_{2} \mathrm{~N}\right), 2.37$ (br.s, $\left.8 \mathrm{H},-\mathrm{NHCH}_{2} \mathrm{CH}_{2} \mathrm{CH}_{2} \mathrm{NH}_{2}\right), 2.69\left(\mathrm{~m}, 8 \mathrm{H},-\mathrm{NHCH}_{2} \mathrm{CH}_{2} \mathrm{CH}_{2} \mathrm{NH}_{2}\right.$ ), $2.73\left(\mathrm{~m}, 8 \mathrm{H},-\mathrm{CH}_{2} \mathrm{CH}_{2} \mathrm{NHCH}_{2} \mathrm{CH}_{2} \mathrm{CH}_{2} \mathrm{NH}_{2}\right), 2.81(\mathrm{~m}, 8 \mathrm{H}$, $-\mathrm{CH}_{2} \mathrm{NHCH}_{2} \mathrm{CH}_{2} \mathrm{CH}_{2} \mathrm{NH}_{2}$ ), 3.27 (br.m, $4 \mathrm{H}_{2},-\mathrm{CH}_{2} \mathrm{NHCH}_{2} \mathrm{CH}_{2}$ ), 3.35 $\left(\mathrm{m}, 8 \mathrm{H},-\mathrm{C}(\mathrm{O}) \mathrm{NHCH}_{2} \mathrm{CH}_{2} \mathrm{CH}_{2} \mathrm{~N}\right), 4.06\left(\mathrm{~s}, 8 \mathrm{H},-\mathrm{OCH}_{2} \mathrm{C}(\mathrm{O}) \mathrm{NH}\right)$, 7.54 (s, 8H, ArH), 8.14 (br.t., $\left.4 \mathrm{H},{ }^{3} J_{\mathrm{HH}}=5.4 \mathrm{~Hz},-\mathrm{C}(\mathrm{O}) \mathrm{NH}\right) \cdot{ }^{13} \mathrm{C}$ NMR $\left(\mathrm{CDCl}_{3}\right) \delta_{\mathrm{C}}$ ppm: 168.20, 156.89, 147.35, 133.42, 127.25, 71.17, 47.93, 47.74, 40.54, 37.74, 34.29, 33.57, 31.11, 29.64. IR v $\mathrm{cm}^{-1}: 3302(\mathrm{NH}) ; 1658,1572,1533(\mathrm{C}(\mathrm{O}) \mathrm{NH})$. MALDI-TOF MS: calculated $\left[\mathrm{M}^{+}\right] \mathrm{m} / z=1404.8$, found $[\mathrm{M}+\mathrm{Na}]^{+} \mathrm{m} / z=1428.1$. Found: C, 61.78; H, 8.51; N, 11.51; S, 8.72. Calculated for $\mathrm{C}_{72} \mathrm{H}_{120} \mathrm{~N}_{16} \mathrm{O}_{8} \mathrm{~S}_{4}$ : C, 61.50; H, 8.32; N, 11.95; S, $9.12 \%$.

\section{UV-Vis Absorption Measurements}

UV-visible spectra were recorded with the Shimadzu UV3600 spectrophotometer using $1 \mathrm{~cm}$ quartz cuvette at $25^{\circ} \mathrm{C}$. DNA sodium salt from calf thymus (CT-DNA) and tris-HCl were purchased from Sigma and were used without further purification. Concentration of the CT-DNA solution was determined using the molar absorptivity $\varepsilon_{260}=6600 \mathrm{~mol}^{-1} \mathrm{~cm}^{-1}$. Purity of DNA was checked by monitoring the ratio of the absorbance, $A_{260} \mid A_{280}>1.8$ indicating DNA was sufficiently free from protein. ${ }^{[24]}$

The solutions were prepared using aqueous buffer $(10 \mathrm{mM}$ Tris- $\mathrm{HCl}, 10 \mathrm{mM} \mathrm{NaCl}, \mathrm{pH}=7.4$ ). Spectra of the thiacalixarene derivatives 3 and 4, CT-DNA and their mixtures were measured in the wavelength range of 190-400 $\mathrm{nm}$. Absorbance measurements were performed by keeping the concentration of the DNA constant $\left(4.41 \cdot 10^{-5} \mathrm{M}\right)$ while varying the thiacalixarene concentrations from $1.94 \cdot 10^{-6}$ to $5.82 \cdot 10^{-6} \mathrm{M}$.

\section{Dynamic Light Scattering (DLS)}

The size distribution of particles formed as a result of selfassembly of thiacalix[4]arene or its interaction with CT-DNA at $25^{\circ} \mathrm{C}$ was determined by DLS method (Zetasizer Nano ZS, Malvern) in polystyrene cuvettes. The analyzer is equipped with a $4 \mathrm{~mW}$ He-Ne laser operating at a wavelength of $633 \mathrm{~nm}$ and incorporates non-invasive backscatter optics (NIBS). Measurements were carried out at the detection angle of $173^{\circ}$ with automatic determination of measurement position inside the cuvettes.

Solutions of the investigated systems with final concentrations within the range from $2.1 \cdot 10^{-6} \mathrm{M}$ to $4.2 \cdot 10^{-4} \mathrm{M}$ for thiacalixarene derivatives $(\mathrm{H})$ and from $4.1 \cdot 10^{-6} \mathrm{M}$ to $1.6 \cdot 10^{-5} \mathrm{M}$ for DNA $(\mathrm{G})$ with different molar ratios $(\mathrm{H}: \mathrm{G}=0.26,0.50,1.0,1.31$, $1.95,2.81,3.9,13.13,100)$ were measured after one hour incubation at room temperature. Results were processed using the Zetasizer software. 


\section{Results and Discussion}

\section{Synthesis of Thiacalix[4]arene Derivatives}

Among the methods frequently reported for the synthesis of amide functionalized thiacalix[4]arenes, direct ester aminolysis is gradually gaining popularity over the previously preferred use of carboxylic acids with coupling agents (DCC, CDI, HOBt etc.) or the use of reactive acyl chlorides. ${ }^{[25,26]}$ This gradual shift to direct aminolysis method is due to the fact that the other methods usually give a mixture of the products and/ or those with poor yield. Unfortunately, even with direct aminolysis, most literature data is limited to the use of diamines as reagents with corresponding bridged products. ${ }^{[26,27]}$

We describe the aminolysis of tetraesters of $p$-tertbutylthiacalix[4]arenes in cone $\mathbf{1}$ and 1,3-alternate $\mathbf{2}$ conformations with the oligoamine bis(3-aminopropyl)amine, resulting in formation of tetrasubstituted compounds (Scheme 1). Generally, aminolysis of tetraesters of $p$-tertbutylthiacalix[4]arenes in the presence of diamines can provide either cyclic or non-cyclic products. ${ }^{[28]}$ The result depends on the spatial structure of a macrocycle, the amine concentration and the length of the linker between the terminal amines. ${ }^{[26-29]}$ The interaction of tetraesters of $p$-tertbutylthiacalix[4]arenes (1 and 2) with a 10-fold excess of the oligoamine - bis(3-aminopropyl)amine - resulted in formation of tetrasubstituted products 3 and 4, respectively. Meanwhile the reaction of the 1,3-alternate conformer $\mathbf{2}$ of the tetraester with bis(3-aminopropyl)amine proceeded only if the reactants were refluxed in the 3:1 toluene:methanol ratio. In the case of the cone conformer 1 the reaction was conducted in the absence of solvent at $60{ }^{\circ} \mathrm{C}$. The interaction of the cone conformer $\mathbf{1}$ with the oligoamine in the presence of the solvent (toluene : methanol) yielded a mixture of the products. This observation can be attributed to the solvent effect as in our previous article. ${ }^{[28]}$ While toluene increased the solubility, methanol as a protic solvent probably decreased the total energy barrier of the system. Hence this resulted in the formation of the mixture of differently substituted products.

In the ${ }^{1} \mathrm{H}$ NMR spectrum of the compound 4 (Figure 1), the signals of tert-butyl, the oxymethylene and the aromatic protons were observed as one singlet at 1.22, 4.06 and $7.54 \mathrm{ppm}$, repsectively. The signals of amide protons gave broadened triplet in a weak field at $8.14 \mathrm{ppm}$ with the spinspin interaction constant ${ }^{3} J_{\mathrm{HH}}=5.4 \mathrm{~Hz}$. Conversely, the signals of the amide protons in bis(3-aminopropyl)amide fragments gave broadened multiplet in a strong field at $3.27 \mathrm{ppm}$. The amine protons are indicated as broadened singlet at $2.37 \mathrm{ppm}$. The protons of each methylene group in the $-\mathrm{NHCH}_{2} \mathrm{CH}_{2} \mathrm{CH}_{2} \mathrm{NH}_{2}$ fragment gave quintet («E») and
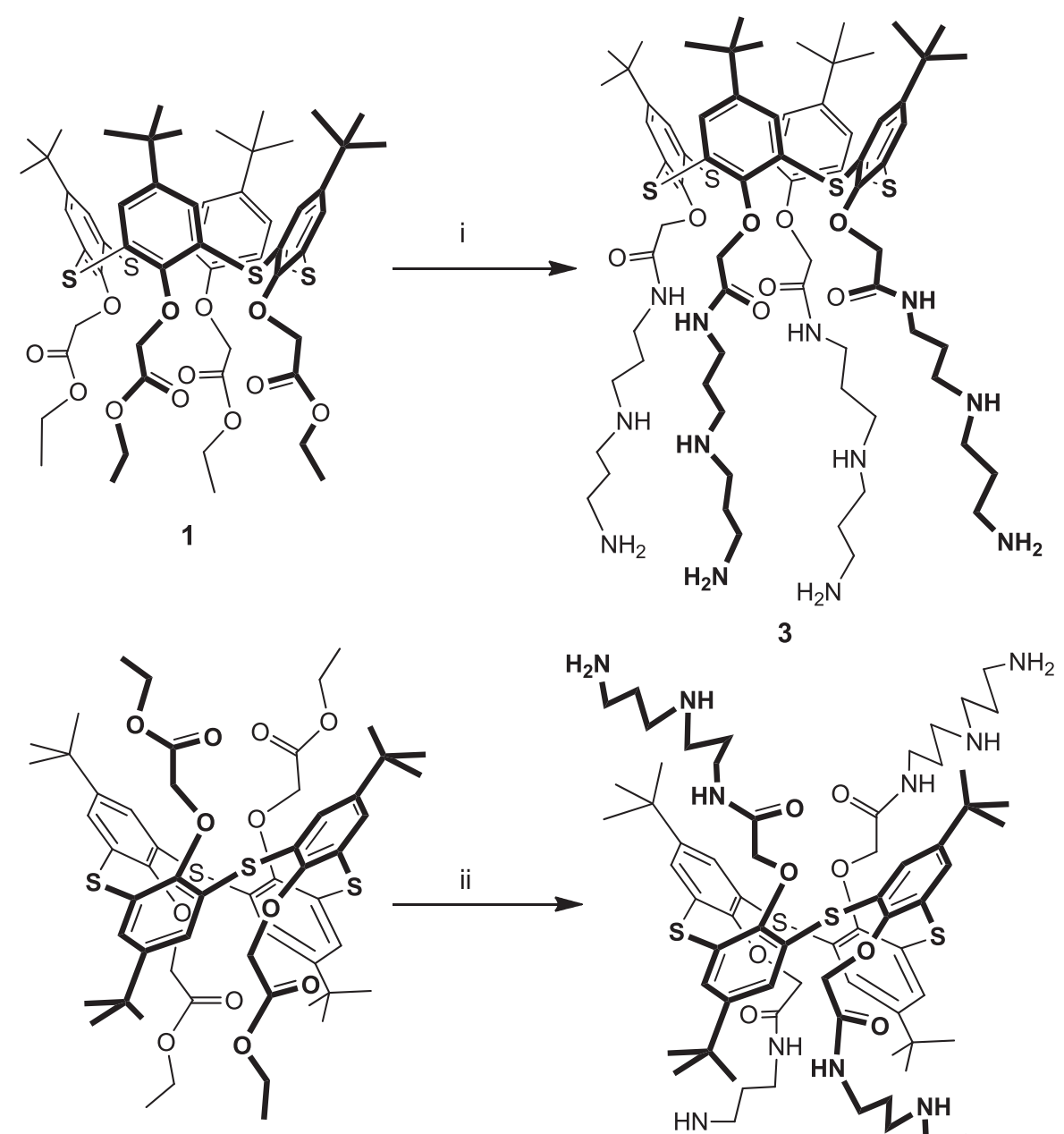

2

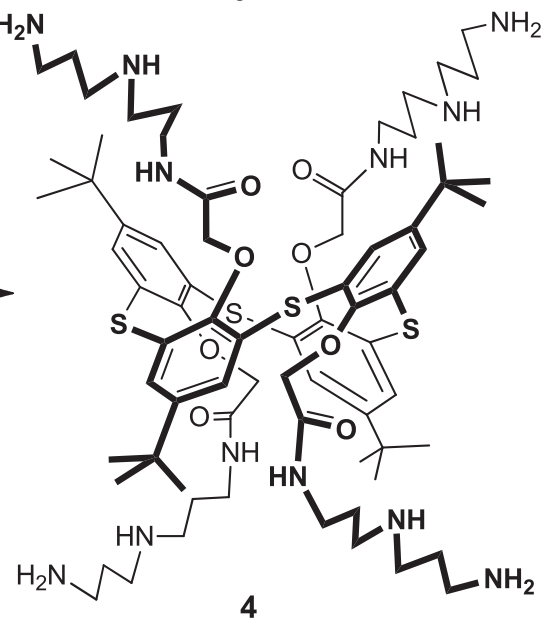

Scheme 1. Reagents and conditions: i - bis(3-aminopropyl)amine; ii - bis(3-aminopropyl)amine, toluene:MeOH (3:1), reflux. 


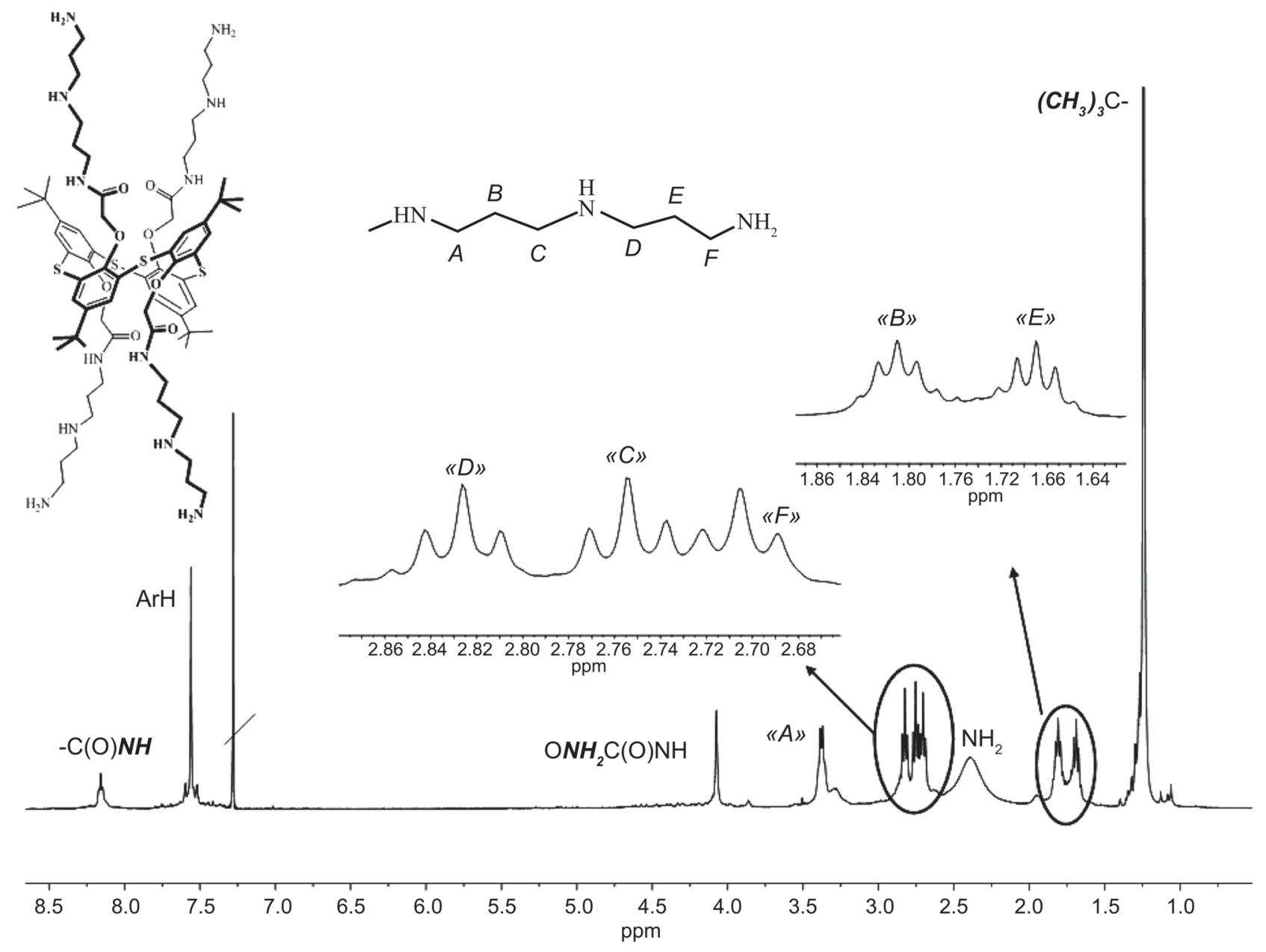

Figure 1. ${ }^{1} \mathrm{H}$ NMR spectrum of compound $4\left(\mathrm{CDCl}_{3}\right.$, at $25^{\circ} \mathrm{C}$, Bruker Avance-400).

multiplets $(« \mathrm{D} », \ll \mathrm{F} »)$ in a field at $1.67,2.81$ and $2.69 \mathrm{ppm}$, respectively. Similarly, the methylene protons of the $-\mathrm{NHCH}_{2} \mathrm{CH}_{2} \mathrm{CH}_{2} \mathrm{NH}$ - fragments were observed as quintet $(« \mathrm{~B} »)$ and multiplets $(« \mathrm{~A} »,\langle\mathrm{C} »)$ in a field at $1.79,3.35$ and $2.73 \mathrm{ppm}$ correspondingly. Thus, the chemical shifts, multiplicity and the integral intensity of the proton signals in ${ }^{1} \mathrm{H}$ NMR spectra of the compound $\mathbf{3}$ and $\mathbf{4}$ are in good agreement with the structure proposed.

As an example, the MALDI-TOF mass spectrum of the tetrasubstituted at the lower rim $p$-tert-butylthiacalix[4] arene $\mathbf{4}$ is shown in Figure 2. The compound in which all the four ethyl esters have successfully undergone aminolysis by four bis(3-aminopropyl)amine molecules was identified $(\mathrm{m} / \mathrm{z}$ $\left.[\mathrm{M}+\mathrm{Na}]^{+}=1428.1\right)$.

Thus, new tetrasubstituted derivatives of thiacalix[4] arene functionalized with bis(3-aminopropyl)amide fragments at the lower rim in the cone and 1,3-alternate conformations 3 and $\mathbf{4}$ were synthesized. The structure of the compounds obtained was characterized by ${ }^{1} \mathrm{H}$ and ${ }^{13} \mathrm{C}$ NMR, IR spectroscopy and mass spectrometry (MALDI-TOF).

\section{UV-Vis Spectroscopy Studies}

To determine the effect of the synthesized thiacalixarene derivatives $\mathbf{3}$ and $\mathbf{4}$ on CT-DNA, UV-Vis spectroscopy and DLS were used to study their interaction with CT-DNA.

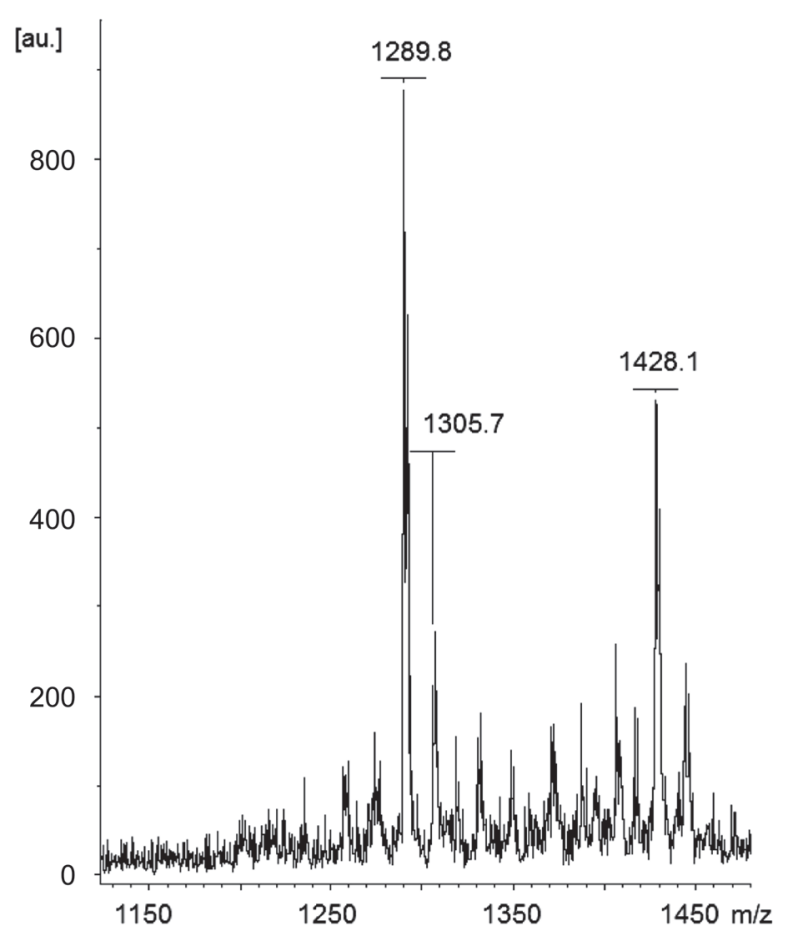

Figure 2. MALDI-TOF mass spectrum of compound 4. 
Serial dilution of the thiacalixarenes $\mathbf{3}$ and $\mathbf{4}$ studied was first performed. The linear dependence of the absorbance against concentration indicated absence of self-aggregation for the compounds 3 and 4 within the $10^{-6} \mathrm{M}$ molar range. It is known that successful interaction of a small molecule with DNA results in a complex characterized by the shift in the absorbance wavelength of DNA and/or appropriate changes in molar absorptivity. Thus, in the absence of a successful interaction, absorbance of individual species in solution is expected to be additive. The UV-vis absorption spectra of DNA in the absence and presence of increasing amounts of thiacalix[4]arene derivatives $\mathbf{3}$ and $\mathbf{4}$ were recorded (Figures 3 and 4 respectively).

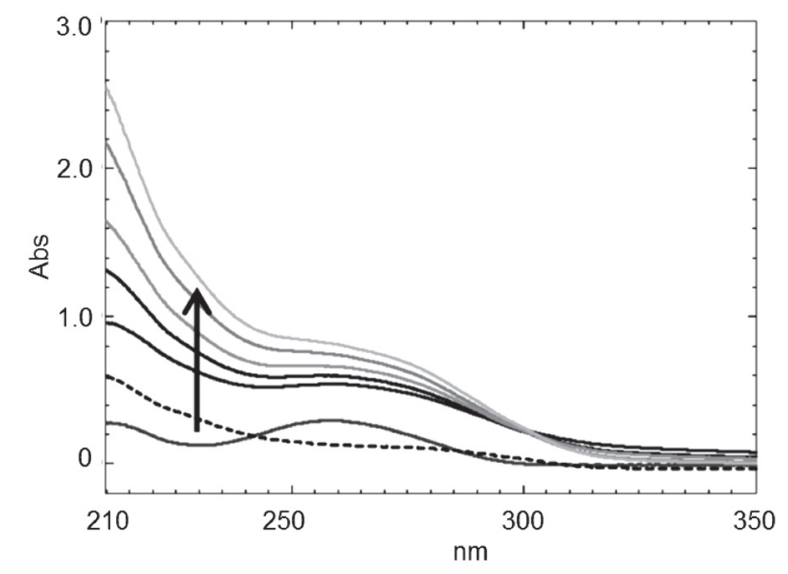

Figure 3. Absorption spectra of CT-DNA in the absence (lower line) and presence of increasing amounts of 3: 1.90, 2.90, 3.59, 4.85 and $5.82 \mu \mathrm{M}$. Dashed-line: 3 in the absence of CT-DNA $(1.94 \mu \mathrm{M})$.

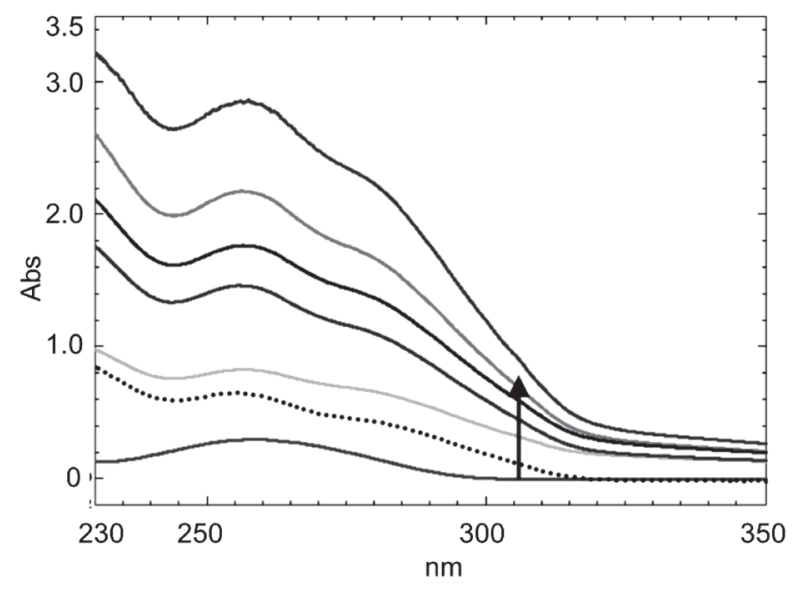

Figure 4. Absorption spectra of CT-DNA in the absence (lower line) and presence of increasing amounts of 4 : 1.94, 3.59, 3.88, 4.85 and $5.82 \mu \mathrm{M}$. Dotted-line: 4 in the absence of CT-DNA $(1.94 \mu \mathrm{M})$.

The interaction of CT-DNA $(44.1 \mu \mathrm{M})$ with increasing concentration of either compound $\mathbf{3}$ or $\mathbf{4}$ (from $1.94 \mu \mathrm{M}$ to $5.82 \mu \mathrm{M})$ resulted in hyperchromic shift in the CT-DNA spectra at $257 \mathrm{~nm}$. Although the absorbance peak at $257 \mathrm{~nm}$ wavelength for CT-DNA increased with increasing concentration of the compounds $\mathbf{3}$ or $\mathbf{4}$, no additivity of the individual absorbances was observed in the mixture. Also, in the spectrum of the $3 / \mathrm{CT}$-DNA complex, an isosbestic point was observed at $300 \mathrm{~nm}$ (Figure 3). The changes observed in the spectra indicate interaction between two individual species in each mixture and thus confirm formation of a complex between the compounds $\mathbf{3}$ or $\mathbf{4}$ and CT-DNA. However, the data obtained is not enough to determine the mode of binding although outside binding can be hypothesized based on the structure of $\mathbf{3}$ and $\mathbf{4}$, and from literature data. ${ }^{[30]}$

\section{DLS Measurements}

We have previously shown by DLS the ability of various thiacalix[4] arene derivatives to either self-associate or form nanoscale particles in the absence or presence of various guests. ${ }^{[25,31-33]}$ Thus, we believe this method can be used to monitor self-aggregation of the compounds $\mathbf{3}$ or $\mathbf{4}$ and their complexation properties toward CT-DNA.

From Table 1 it can be noticed that the increase in molar ratio, 3/CT-DNA, from 0.26 to 3.90 is accompanied by a decrease in the main particle size for the 3/CT-DNA complex from $1862 \mathrm{~nm}(91.4 \%)$ to $41.9 \mathrm{~nm}(62.6 \%)$. A second main particle (peak area intensity $\leq 49 \%$ ) forms by self-aggregation of $\mathbf{3}$. Further increase in the molar ratio to 13.13 resulted in increased particle size yielding approximate size equality of two main particles, i.e., 167.6 (50.8\%) and $132.6(44.9 \%) \mathrm{nm}$. This might be due to clustering of excess amounts of the $\mathbf{3}$ molecules around the already formed nanosized particles of $3 /$ CT-DNA complex. The interaction of 4 with CT-DNA follows similar trend. However, in this case, the main particle size reduced to around $79.9 \mathrm{~nm}$ only $(87.8 \%)$ with corresponding molar ratio for $4 / C T-D N A$ equal to 3.90. Also, the concentration of the second major particle was significantly lower (peak area intensity $\leq 10 \%$ ), its size was mostly above $1 \mu \mathrm{m}$. This indicated self-aggregation of 4. This was confirmed by the presence of larger particles (4076 nm, 9.1\%) observed by DLS for 4 in the absence of CT-DNA. The system was polydispersed thus there was more than one peak in the various molar ratios studied.

\section{Conclusion}

Thus, new tetrasubstituted derivatives of thiacalix[4] arene functionalized with bis(3-aminopropyl)amide fragments at the lower rim in the cone and 1,3-alternate conformations $\mathbf{3}$ and $\mathbf{4}$ were synthesized. The interaction of two multifunctional reagents (tetraesters $\mathbf{1}$ and $\mathbf{2}$ and bis(3-aminopropyl)amine) expected in the conditions of oligoamine excess the target products with four primary amino groups were formed both for the cone and 1,3-alternate conformations. The interaction of the synthesized thiacalix[4] arenes derivatives with DNA was also demonstrated by shift in the absorption maxima to $257 \mathrm{~nm}$ with clear isosbestic point at $300 \mathrm{~nm}$.

It was shown that an increase in molar ratio of 3/CT-DNA and 4/CT-DNA from 0.26 to 3.90 decreased the main particle size. However, further increase in the concentration of hosts $\mathbf{3}$ and $\mathbf{4}$ resulted in formation of two main particles of approximately equal size (167.6 and $132.6 \mathrm{~nm}$, respectively) due to clustering of the excess host molecules around the nanosized particles of the host/CT-DNA complex formed. 
Thiacalix[4]arenes Functionalized with Aminopropylamides at the Lower Rim: Synthesis and Interaction with DNA

Table 1. Size of aggregates (diameters, $d_{1}, d_{2}, d_{3}(\mathrm{~nm})$, and peak area intensity, $S_{1}, S_{2}, S_{3}(\%)$, for the peaks 1,2 and 3 , respectively) obtained for complexes of the compounds $\mathbf{3}$ and $\mathbf{4}$ with CT-DNA in water and appropriate polydispersity index (PDI).

\begin{tabular}{cccccc}
\hline $\begin{array}{c}\text { Molar Ratio } \\
{[\mathrm{H}] /[\mathrm{G}]}\end{array}$ & $\mathrm{H}, \mathrm{G}$ & $d_{1}, \mathrm{~nm}\left(S_{1}, \%\right)$ & $d_{2}, \mathrm{~nm}\left(S_{2}, \%\right)$ & $d_{3}, \mathrm{~nm}\left(S_{3}, \%\right)$ & PDI \\
\hline $0.0 / 1.6 \cdot 10^{-5}$ & $\mathrm{CT}-\mathrm{DNA}$ & $2612 \pm 1561(95.3)$ & $106.6 \pm 126.6(4.7)$ & - & $0.65 \pm 0.34$ \\
\hline \multirow{2}{*}{$4.2 \cdot 10^{-4} / 0.0$} & $\mathbf{3}$ & $394.3 \pm 85.5(74.4)$ & $21.7 \pm 37.7(15.6)$ & $58.8 \pm 40.5(10.0)$ & $0.78 \pm 0.11$ \\
\hline \multirow{2}{*}{0.26} & $\mathbf{4}$ & $171.9 \pm 7.5(88.2)$ & $4076 \pm 701(9.1)$ & $26.0 \pm 13.6(2.7)$ & $0.37 \pm 0.01$ \\
\hline \multirow{2}{*}{1.0} & $\mathbf{3}$ & $1862 \pm 730(91.4)$ & $2603 \pm 287(8.6)$ & - & $0.44 \pm 0.09$ \\
& $\mathbf{4}$ & $1021 \pm 114(96.9)$ & $3597 \pm 270(3.1)$ & - & $0.30 \pm 0.03$ \\
\hline \multirow{2}{*}{1.95} & $\mathbf{3}$ & $74.8 \pm 39.1(68.9)$ & $1035 \pm 186(29.2)$ & $1577 \pm 249(1.9)$ & $0.40 \pm 0.08$ \\
& $\mathbf{4}$ & $99.1 \pm 19.9(98.8)$ & $2580 \pm 283(1.1)$ & $3.8 \pm 0.93(0.1)$ & $0.28 \pm 0.05$ \\
\hline \multirow{2}{*}{3.90} & $\mathbf{3}$ & $50.4 \pm 10.3(66.1)$ & $264.6 \pm 87.5(31.1)$ & $2538 \pm 279(2.8)$ & $0.46 \pm 0.15$ \\
& $\mathbf{4}$ & $83.5 \pm 8.8(89.4)$ & $1483 \pm 214(8.4)$ & $1873 \pm 257(2.3)$ & $0.38 \pm 0.07$ \\
\hline \multirow{2}{*}{13.13} & $\mathbf{3}$ & $41.9 \pm 9.2(62.6)$ & $254.1 \pm 71.78(35.7)$ & $1734 \pm 269(1.7)$ & $0.42 \pm 0.06$ \\
& $\mathbf{4}$ & $79.9 \pm 11.8(87.8)$ & $1264 \pm 254(19.9)$ & $1763 \pm 273(0.9)$ & $0.35 \pm 0.09$ \\
\hline
\end{tabular}

Acknowledgements. The work was supported by the Russian Foundation for Basic Research (grant no. 12-03-000252-a, 13-03-12055-ofi_m).

\section{References}

1. Langer R., Tirrell D. Nature 2004, 428 (6982), 487-492.

2. Chen K., Andr M., Wang H., Tseng H. Supramolecular Nanoparticles for Molecular Diagnostics and Therapeutics. John Wiley \& Sons, Ltd, 2012. 177 p.

3. N'soukpoé-Kossi C.N., Ouameur A.A., Thomas T., Shirahata A., Thomas T.J., Tajmir-Riahi H.A. Biomacromolecules 2008, 9, 2712-2718.

4. Nakai C., Glinsmann W. Biochemistry 1977, 16(25), 56365641.

5. Galukhin A.V., Stoikov I.I. Mendeleev Commun. 2014, 24(2), 82-84.

6. Andreyko E.A., Padnya P.L., Daminova R.R., Stoikov I.I. RSC Adv. 2014, 4(7), 3556-3565.

7. Galukhin A.V., Shabalin K.V., Antipin I.S., Konovalov A.I., Stoikov I.I. Mendeleev Commun. 2013, 23, 41-43.

8. Galukhin A.V., Zaikov E.N., Antipin I.S., Konovalov A.I., Stoikov I.I. Macroheterocycles 2012, 5, 266-274.

9. Mostovaya O.A., Agafonova M.N., Galukhin A.V., Khayrutdinov B.I., Islamov D., Kataeva O.N., Antipin I.S., Konovalov A.I., Stoikov I.I. J. Phys. Org. Chem. 2014, 27, 57-65.

10. Fischer W., Calderón M., Haag R. Top Curr. Chem. 2010, 296, 95-129.

11. Merdan T., Kopecek J., Kissel T. Adv. Drug Deliv. Rev. 2002 , 54(5), 715-758.

12. Tziveleka L.-A., Psarra A.-M.G., Tsiourvas D., Paleos C.M. J. Control Release 2007, 117(1), 137-146.

13. Zhong H., He Z.-G., Li Z., Li G.-Y., Shen S.-R., Li X.-L. J. Biomater. Appl. 2008, 22(6), 527-544.

14. Vu L., Ramos J., Potta T., Rege K. Theranostics 2012, 2, 1160 1173.

15. Yang C., Wang X., Li H., Tan E., Lim C.T., Li J. J. Phys. Chem. B 2009, 113(22), 7903-7911.
16. Faizullin D.A., Vylegzhanina N.N., Gnezdilov O.I., Salnikov V.V., Galukhin A.V., Stoikov I.I., Antipin I.S., Zuev Y.F. Appl. Magn. Reson. 2011, 40, 231-243.

17. Rodik R.V., Klymchenko A.S., Jain N., Miroshnichenko S.I., Richert L., Kalchenko V.I., Mély Y. Chemistry 2011, 17, 55265538.

18. Kunath K., Von Harpe A., Fischer D., Petersen H., Bickel U., Voigt K., Kissel T. J. Control Release 2003, 89, 113-125.

19. Pan S., Cao D., Huang H., Yi W., Qin L., Feng M. Macromol. Biosci. 2013, 13, 422-436.

20. Dunlap D.D., Maggi A., Soria M.R., Monaco L. Nucleic Acids Res. 1997, 25, 3095-3101.

21. Bagnacani V., Franceschi V., Bassi M., Lomazzi M., Donofrio G., Sansone F., Casnati A., Ungaro R. Nat. Commun. 2013, 4, 1721-1727.

22. Iki N., Miyano S. J. Incl. Phenom. Macrocycl. Chem. 2001, 41, 99-105.

23. Iki N., Narumi F., Fujimoto T., Morohashi N., Miyano S. J. Chem. Soc., Perkin Trans. 2 1998, 2745-2750.

24. Marmur J. Methods Enzymol. 1963, 6, 726-738.

25. Stoikov I.I., Yushkova E.A., Zhukov A.Y., Zharov I., Anti-pin I.S., Konovalov A.I. Tetrahedron 2008, 64, 7112-7121.

26. Padnya P.L., Andreyko E.A., Harisova A.Z., Zuev Y.F., Stoikov I.I. Butlerov Commun. 2013, 34(5), 1-10.

27. St’astný V., Stibor I., Císarová I., Sýkora J., Pojarová M., Lhoták P. J. Org. Chem. 2006, 71, 5404-5406.

28. Puplampu J.B., Yakimova L.S., Vavilova A.A., Fayzullin D.A., Zuev Y.F., Stoikov I.I. Macroheterocycles 2014, 7, 337-344.

29. Chakrabarti A., Chawla H. M., Pant N., Singh S. P., Upreti S., Tetrahedron 2006, 62, 8974-8981.

30. Hu W., Blecking C., Kralj M., Šuman L., Piantanida I., Schrader T. Chemistry 2012, 18, 3589-3597.

31. Stoikov I.I., Yushkova E.A., Zhukov A.Y., Zharov I., Antipin I.S., Konovalov A.I. Tetrahedron 2008, 64, 7489-7497.

32. Yushkova E.A., Stoikov I.I., Zhukov A.Y., Puplampu J.B., Rizvanov I. K., Antipin I.S., Konovalov A.I. RSC Adv. 2012, 2, 3906-3919.

33. StoikovI.I.,YushkovaE.A.,BukharaevA.A.,BiziaevD.A.,Ziganshina S.A., Zharov I. J. Phys. Chem. C 2009, 113, 15838-15844. 